\title{
FORMULATION AND EVALUATION OF ANTIFUNGAL CREAM OF CHLORPHENESIN
}

\author{
VEENA S. ${ }^{*}{ }^{*}$, SURINDER KAUR ${ }^{2}$, GURURAJ KULKARNI ${ }^{3}$ \\ 1,2,3Department of Pharmaceutics, the Oxford College of Pharmacy, Bangalore, Karnataka 560068, India \\ Email: vv121643@gmail.com
}

Received: 04 May 2021, Revised and Accepted: 02 Jul 2021

\section{ABSTRACT}

Objective: The main aim of our research was to develop an Antifungal cream formulation consisting of Chlorphenesin for the treatment of Fungal infections. Topical route is the most suitable route for skin infections.

Methods: The development of topical drug delivery systems designed to have systemic effects appears to be beneficial for a number of drugs on account of several advantages over conventional dosage forms(or) routes of drug administration. An Antifungal cream formulation consisting of Chlorphenesin was prepared.

Results: The formulation was subjected to in vitro diffusion studies. Microbiological studies were performed to find out the safety of materials used in the formulation.

Conclusion: The developed cream consisting of Cholrphnesin was found to be safe and effective for the treatment of fungal infection.

Keywords: Fungal infection, Chlorphenesin, Antifungal cream

(C) 2021 The Authors. Published by Innovare Academic Sciences Pvt Ltd. This is an open access article under the CC BY license (https://creativecommons.org/licenses/by/4.0/) DOI: https://dx.doi.org/10.22159/ijcpr.2021v13i5.1898 Journal homepage: https://innovareacademics.in/journals/index.php/ijcpr

\section{INTRODUCTION}

Several antifungal agents are available on the market in different topical preparations (e. g., creams, ointments, and powders for the purpose of local dermatological therapy). One of these antifungal agents is chlorphenesin (CHL), which has both anti-fungal and antibacterial properties. It is applied locally in mild uncomplicated dermatophyte and other cutaneous infections $[1,2]$.

Fungal infections (also called mycoses) represent the invasion of tissues by one or more species of fungi which may cause superficial, localized, deeper tissue infections to serious lung, blood (septicemia) or systemic diseases. Some fungi are pathogenic, causing disease whether the immune system is healthy or not [3].

Topical treatment of fungal infections has several superiorities including, targeting the site of infection, reduction of the risk of systemic side effects, enhancement of the efficacy of treatment and, high patient compliance. Different type of topical effective antifungal compounds has been used in the treatment of a variety of dermatological skin infections.
Currently, these antifungal drugs are commercially available in conventional dosage forms such as creams, gels, lotions and sprays [4].

The most common therapeutic options are systemic and topical antifungal agents; however, oral antifungals are associated with adverse effects that can cause patients to discontinue treatment, which may be complicated by the presence of comorbid conditions [5].

Antifungal drugs should reach effective therapeutic levels in viable epidermis after dermal administration. The greatest challenge for dermal delivery is stratum corneum, in order to improve its permeability, new formulation approaches have been investigated $[6,7]$.

\section{MATERIALS AND METHODS}

\section{Materials}

Propylene glycol, bees wax, stearyl alcohol, cetyl alcohol, Triethanolamine, propylparaben, methyl paraben, liquid paraffin. Stearic acid And Cholrphenesin were purchased from NS Chemicals, New Mumbai.

Table 1: Formulae for cream base

\begin{tabular}{|c|c|c|c|c|c|c|c|c|c|c|}
\hline & \multirow[t]{2}{*}{ S. No. } & \multirow[t]{2}{*}{ Ingredients } & \multicolumn{8}{|c|}{ Quantity in gm (20 gm) } \\
\hline & & & F1 & F2 & F3 & F4 & F5 & F6 & F7 & F8 \\
\hline \multirow[t]{6}{*}{ Oil phase (A) } & 1 & Stearic acid & 3 & 3.5 & 4 & 4.5 & 4 & 4.5 & 5 & 5 \\
\hline & 2 & Cetyl alcohol & 0.1 & 0.2 & 0.1 & 0.2 & - & - & - & - \\
\hline & 3 & Potassium Hydroxide & - & 0.1 & 0.2 & 0.3 & - & - & - & - \\
\hline & 4 & Sodium Hydroxide & 0.03 & 0.02 & 0.01 & - & - & - & - & - \\
\hline & 5 & Coconut oil & - & - & - & - & 1 & 2 & 3 & 4 \\
\hline & 6 & Liquid Paraffin & - & 0.5 & 1 & 1.5 & 3 & 3 & 3 & 3 \\
\hline Aqueous & 7 & Glycerine & 1 & 1.5 & 2 & 2.5 & 3 & 3 & 3 & 3 \\
\hline \multirow[t]{6}{*}{ phase (B) } & 8 & Triethanolamine & - & - & - & - & 1.5 & 1.5 & 1.5 & 1.5 \\
\hline & 9 & Methyl Paraben & 0.04 & 0.03 & 0.04 & 0.02 & 0.02 & 0.02 & 0.02 & 0.02 \\
\hline & 10 & Propyl Paraben & 0.04 & 0.03 & - & 0.02 & 0.02 & 0.02 & 0.02 & 0.02 \\
\hline & 11 & Aloe vera gel & - & - & - & - & 2 & 4 & 6 & 8 \\
\hline & 12 & Perfume & Qs & qs & Qs & qs & qs & qs & Qs & qs \\
\hline & 13 & Water & $\begin{array}{l}\text { qs to } 20 \\
\mathrm{ml}\end{array}$ & $\begin{array}{l}\text { qs to } 20 \\
\mathrm{ml}\end{array}$ & $\begin{array}{l}\text { qs to } 20 \\
\mathrm{ml}\end{array}$ & $\begin{array}{l}\text { qs to } 20 \\
\mathrm{ml}\end{array}$ & $\begin{array}{l}\text { qs to } 20 \\
\mathrm{ml}\end{array}$ & $\begin{array}{l}\text { qs to } 20 \\
\mathrm{ml}\end{array}$ & $\begin{array}{l}\text { qs to } 20 \\
\mathrm{ml}\end{array}$ & $\begin{array}{l}\text { qs to } 20 \\
\text { ml }\end{array}$ \\
\hline
\end{tabular}




\section{Preparation of $\mathrm{o} / \mathrm{w}$ cream formulation}

These $\mathrm{o} / \mathrm{w}$ emulsion-based preparations contain the aqueous phase and oil phase. The ingredients of oil phase (A) were mixed together by melting in a china dish at $70{ }^{\circ} \mathrm{C}$ on a water bath with constant stirring. The components of the aqueous phase (B) were mixed together separately in a beaker and heated about the same temperature as of the oil phase on a water bath. The aqueous phase was added to the oil phase drop by drop with constant stirring using an emulsifier. The therapeutically active Chlorphenesin is dissolved in distilled water and add to the above mixture and stir continuously until formation of cream. The preservatives propylparaben and methylparaben were added after cooling to $40^{\circ} \mathrm{C}$.

\section{RESULTS}

\section{Evaluation parameters}

Take about 1 gram of cream in a clean petri dish and observe visually.

\section{Infrared spectral analysis}

IR spectral analysis is one of the most powerful analytical techniques which offer possible chemical identification. In the present work, IR spectrum of Chlorphenesin pure drug and Chlorphenesin along with other excipients in the formulation was studied for their interactions [8].

The results are shown in table 2 to 7 , and fig. 1 to 3 .

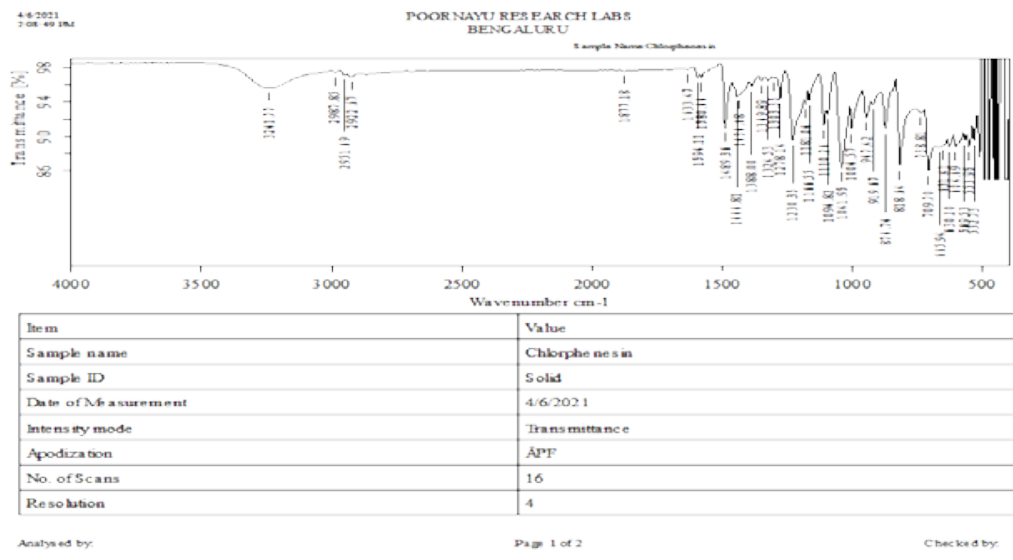

Fig. 1: FTIR-graph of pure chlorphenesin API

IR Spectrum of pure drug Chlorphenesin exhibited its characteristic absorption bonds in the following IR region in, and showed in table 4 and 5

Table 2: R Spectrum of pure drug chlorphenesin exhibited its characteristic absorption bonds

\begin{tabular}{lll}
\hline Frequency & Bonds & Inference \\
\hline $3241.77 \mathrm{~cm}^{-1}(3190-3390)$ & Broad peak & Broad peak due to hydrogen bonded O-H stretching \\
& & \\
& Table 3: IR Interpretation of chlorphenesin \\
\hline Wavelength & Group \\
\hline $2987.85 \mathrm{~cm}-1$ & Aromatic C-H Stretch \\
2951.69 and $2922.67 \mathrm{~cm}-1$ & C-H Stretching of CH ${ }_{2}$ Group \\
$1633.47,1594.11,1580.44,1489.36 \mathrm{~cm}-1$ & C=C Ring Stretching \\
1444.81 and $1388.00 \mathrm{~cm}-1$ & C-H Bonding of $\mathrm{CH}_{2}$ Group \\
$1278.14 \mathrm{~cm}^{-1}$ & O-H Bonding \\
$1094.82 \mathrm{~cm}^{-1}$ & C-O-C \\
$818.64 \mathrm{~cm}^{-1}$ & Para Substitutional Benzene \\
$665.94 \mathrm{~cm}^{-1}$ & C-Cl \\
\hline
\end{tabular}

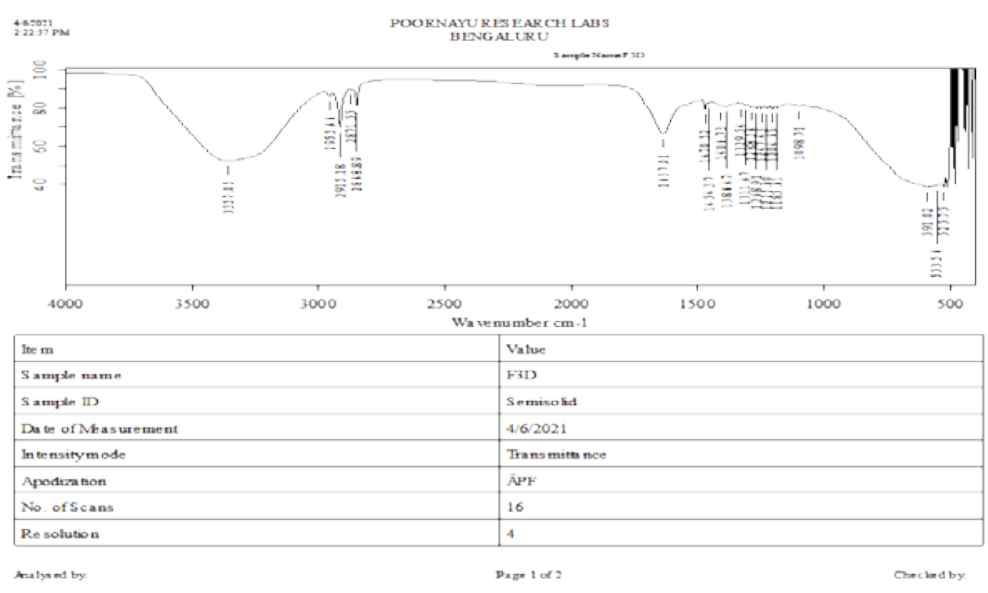

Fig. 2: FTIR-graph of pure chlorphenesin with other excipients 
IR Spectrum of Chlorphenesin with other excipients exhibited its characteristic absorption bonds in the following IR region in

Table 4: IR Spectrum of chlorphenesin with other excipients exhibited its characteristic absorption bonds

\begin{tabular}{lll}
\hline Frequency & Bonds & Inference \\
\hline $3351 \mathrm{~cm}^{-1}(3190-3390)$ & Broad peak & $\begin{array}{l}\text { Some OH peaks of excipients must have merged with OH peaks of the drug. Hence } \\
\text { very broad peak of hydrogen-bonded O-H stretching. }\end{array}$ \\
\hline
\end{tabular}

Table 5: IR Interpretation of chlorphenesin with other excipients

\begin{tabular}{ll}
\hline Wavelength & Group \\
\hline 2954.69 and $2917.48 \mathrm{~cm}-1$ & C-H Stretching of $\mathrm{CH}_{2}$ groups \\
$1641.87,1580.49,1462.46 \mathrm{~cm}-1$ & C=C Ring Stretching \\
1430.76 and $1377.11 \mathrm{~cm}-1$ & C-H bonding of $\mathrm{CH}_{2} \mathrm{Group}^{-1}$ \\
$1271 \mathrm{~cm}-1$ & O-H Bonding \\
$1098.32 \mathrm{~cm}^{-1}$ & $\mathrm{C}-\mathrm{O}-\mathrm{C}$ \\
$674.17 \mathrm{~cm}^{-1}$ & $\mathrm{C}-\mathrm{Cl}$ \\
\hline
\end{tabular}

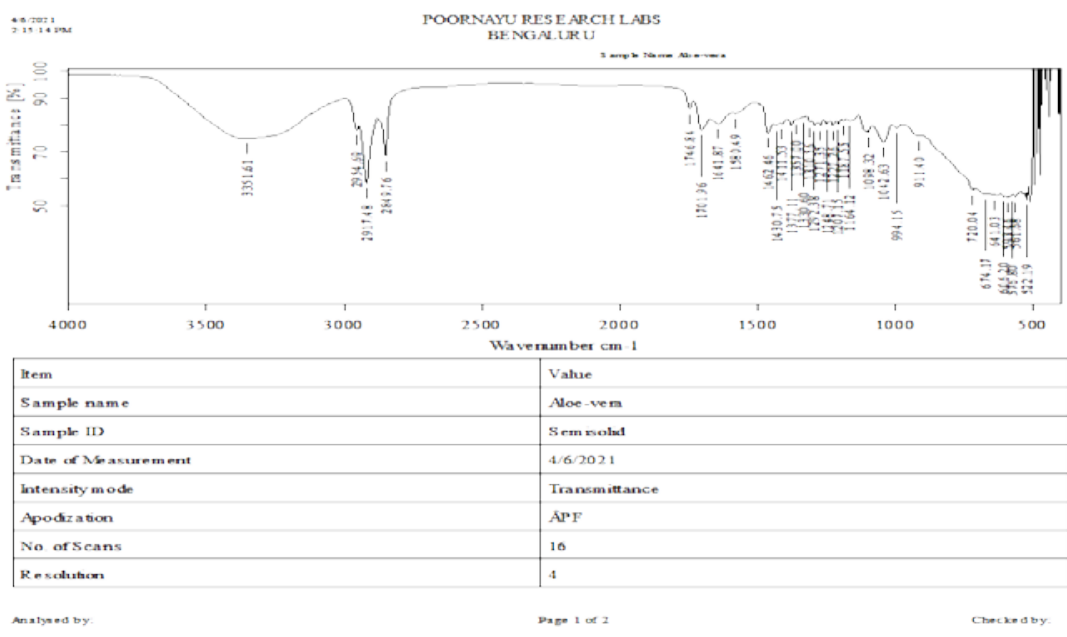

Fig. 3: FTIR-graph of pure chlorphenesin with other excipients and Aloe vera gel

IR Spectrum of Chlorphenesin with other excipients and Aloe vera gel exhibited its characteristic absorption bonds in the following IR region in

Table 6: IR Spectrum of chlorphenesin with other excipients and aloe vera gel exhibited its characteristic absorption bonds

\begin{tabular}{lll}
\hline Frequency & Bonds & Inference \\
\hline $3357 \mathrm{~cm}^{-1}(3190-3390)$ & Broad peak & Hydrogen bonded O-H Stretching of OH groups \\
\hline
\end{tabular}

Table 7: IR Interpretation of chlorphenesin with other excipients and aloe vera gel

\begin{tabular}{ll}
\hline Wavelength & Group \\
\hline 2955.46 and $2915.18 \mathrm{~cm}-1$ & C-H Stretching of $\mathrm{CH}_{2}$ groups \\
$1637,1470.52 \mathrm{~cm}-1$ & C=C Ring Stretching \\
1454.36 and $1386.47 \mathrm{~cm}-1$ & C-H bonding of $\mathrm{CH}_{2} \mathrm{Group}^{-1}$ \\
$1268 \mathrm{~cm}-1$ & O-H Bonding \\
$1098.71 \mathrm{~cm}^{-1}$ & $\mathrm{C}-\mathrm{O}-\mathrm{C}$ \\
650 and $591 \mathrm{~cm}^{-1}$ & $\mathrm{C}-\mathrm{Cl}$ \\
\hline
\end{tabular}

\section{Physical examination}

The prepared topical creams were inspected visually for their color, homogeneity, consistency, spreadability and phase separation. The results are shown in table 8 and 9 .

\section{Determination of $\mathrm{pH}$}

Weigh about $5 \mathrm{gm}$ of the cream and dispersed in $45 \mathrm{ml}$ of water in a $100 \mathrm{ml}$ beaker. The $\mathrm{pH}$ was determined at $27^{\circ} \mathrm{C}$ using the $\mathrm{pH}$ meter. The results are shown in table 8 and 9 [9].

\section{Viscosity}

The viscosity of formulated creams was measured by Brook field Viscometer LVD using spindle S 94 at varying speed and shear rates. The measurements were done over the range of speed setting from $0.10,0.20,0.30,0.40$ and $0.50 \mathrm{rpm}$ in $60 \mathrm{~s}$ between two successive speeds as equilibration with the shear rate ranging from $0.20 \mathrm{~s}-1$ to $1.0 \mathrm{~s}-1$. Viscosity determinations were performed at room temperature [10]. The results are shown in the table 10 and fig. 4 
Table 8: Physico-chemical evaluation of formulation

\begin{tabular}{lllll}
\hline S. No. & Formulation code & Appearance & pH & Consistency \\
\hline 1 & F1 & White & 7.08 & Poor(liquid) \\
2 & F2 & White & 7.06 & Hard (solid) \\
3 & F3 & White & 7.1 & Creamy \\
4 & F4 & White & 6.8 & Creamy \\
5 & F5 & White & 6.86 & Creamy \\
6 & F6 & White & 6.81 & Creamy \\
7 & F7 & White & 6.8 & Creamy (smooth) \\
8 & F8 & White & & \\
\hline
\end{tabular}

All the above formulations contain $0.3 \%$ of Chlorphenesin, From the above results, F8 formulation is considered as the finally optimized formulae, and that formulation was evaluated with the process such as homogenizer speed (RPM), time of homogenization, water bath temperature, sampling points. Further studies is carried out and are evaluated for parameters such as $\mathrm{pH}$, spread ability, drug content, diffusion and stability studies.

Table 9: Physico-chemical evaluation of F8 formulation and marketed product

\begin{tabular}{|c|c|c|c|c|c|c|}
\hline & Trial code & Appearance & pH & Drug content & Tube extrudability & Spreadability \\
\hline 1 & Marketed product & White & 6.8 & 98.42 & $98.7 \%$ & 18.3 \\
\hline 2 & F8 & White & 6.7 & 97.60 & $98.6 \%$ & 18.5 \\
\hline
\end{tabular}

Table 10: Viscosity data of prepared cream formulation F8 containing $0.3 \%$ of chlorphenesin

\begin{tabular}{llll}
\hline S. No. & RPM & Centripois & Torq \\
\hline 1 & 10 & 287 & 2.3 \\
2 & 20 & 192 & 3.2 \\
3 & 30 & 148 & 3.7 \\
4 & 50 & 120 & 5 \\
5 & 60 & 104 & 5.4 \\
6 & 100 & 82 & 6.9 \\
\hline
\end{tabular}

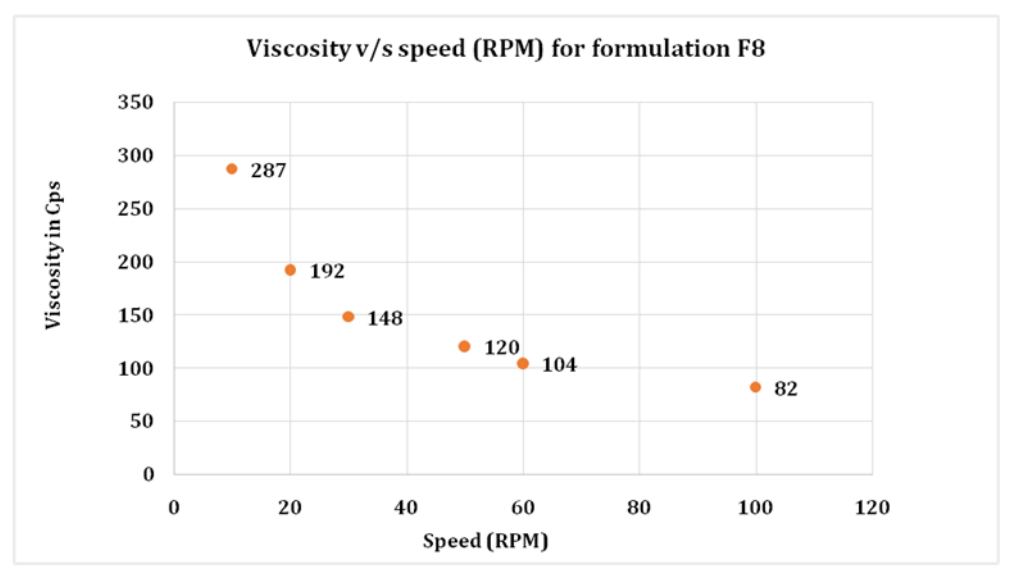

Fig. 4: Viscosity v/s speed (RPM) for formulation F8

\section{Tube extrucibility}

In the present study, the method adopted for evaluating cream formulation for extrudability was based upon the quantity in percentage cream extruded from tube on the application of finger pressure. More quantity extruded better the extrudability.

The formulations under study were filled in a clean, lacquered aluminum collapsible 5 grams tube with a nasal tip of $5 \mathrm{~mm}$ opening. The pressure was applied on the tube by holding it in between the thumb and index finger for $1 \mathrm{sec}$. Tube extrudability was then determined by measuring the amount of cream extruded through the tip when the pressure was applied [8]. The results are shown in table 8.

\section{In vitro drug diffusion}

A glass cylinder with both ends open, $10 \mathrm{~cm}$ height, $3.7 \mathrm{~cm}$ outer diameter and $3.1 \mathrm{~cm}$ inner diameter was used as permeation cell. A cellophane membrane prehydrated in $\mathrm{pH} 7.4$ buffer $(24 \mathrm{~h}$. before use) was fixed to one end of the cylinder with the aid of an adhesive to result in permeation. One gram of semisolid formulation was taken in the cell (donor compartment) and the cell was attached to a beaker containing $140 \mathrm{ml}$ of drug-free $\mathrm{pH} 7.4$ phosphate buffer as receptor compartment. The medium in the receptor compartment was agitated using a magnetic stirrer and a temperature of $37{ }^{\circ} \mathrm{C} \pm 1$ ${ }^{\circ} \mathrm{C}$ was maintained. Samples of $1 \mathrm{ml}$ from the receptor compartment were taken at various intervals over a period of $3 \mathrm{~h}$ with replacement of an equal amount of drug-free buffer (7.4 Phosphate). The samples were estimated by measuring the absorbance at 279 $\mathrm{nm}$ in a UV-1700 Shimadzu spectrophotometer [11]. The results are shown in table 12

Table 11: In vitro drug diffusion studies

\begin{tabular}{lll}
\hline S. No. & Time interval (min) & \%CDR F8 \\
\hline 1 & 30 & 30.01 \\
2 & 60 & 40.25 \\
3 & 90 & 50.58 \\
4 & 120 & 65.74 \\
5 & 150 & 80.95 \\
6 & 180 & 96.19 \\
\hline
\end{tabular}




\section{In vitro antimicrobial studies}

Topical formulation with broad, non-resistance promoting activity against Aspergillus Niger can be of great use in dermatology preparation were infections are often mixed. Since formulation containing antifungal agent as active moiety, it is likely to protect from fungal growth. To determine the activity of formulation is subject to study the prepared formulation with standard method called Disk diffusion method and the inhibition zone diameters were measured with the help of zone reader. The results are shown in the table 12 and fig. 5.

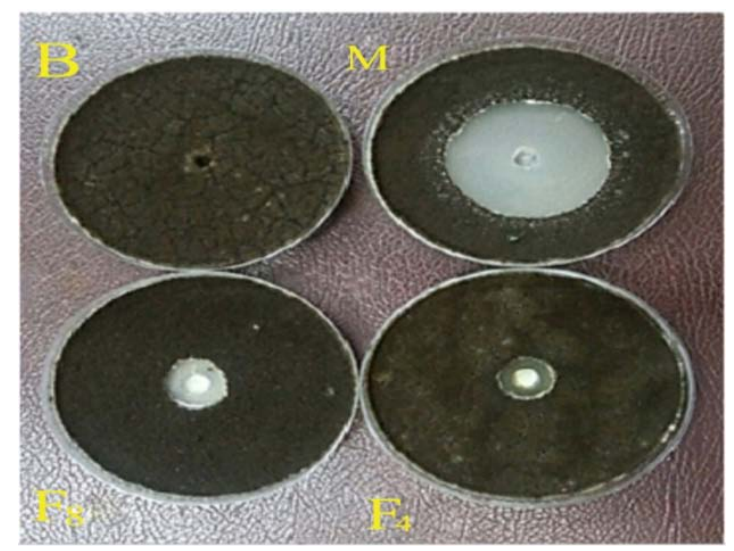

Fig. 5: In vitro antifungal studies showing zone of inhibition, (B: Blank, M: marketed product, F8: Formulation 8, F4: Formulation 4)

Table 12: Zone of inhibition of chlorphenesin and marketed cream (Clotrimazole)

\begin{tabular}{ll}
\hline Drugs & Zone of inhibition (mm) \\
\hline BLANK (B) (without drug) & 00 \\
Marketed product (M) & 42 \\
F8 & 19 \\
F4 & 18 \\
\hline
\end{tabular}

\section{DISCUSSION}

From the above-compiled data, the study clearly shows that the formulation is showing good in vitro antifungal activity against Aspergillus Niger.

As a part my research work, Infra-red spectra of pure drug Chlorphenesin and its formulation are taken interpretation of above IR spectra reveals that the characteristic absorption bonds of different function groups and bonds present in the drug are present in both formulations, The positions of characteristics bonds of pure drug also presence in the spectra of its formulations. Even if slight variation in the position of absorption bonds is observed it is negligible and it is within the permissible range, this clearly suggests that there is no interaction of the drug with excipients used in the preparation of formulations. Hence it may be concluded that the drug has no interaction with the excipients used and thus, there is drug-excipients compatibility [12-22].

\section{CONCLUSION}

The formulation of the antifungal agent Chlorphenesin exhibited an enhanced rate of diffusion and anti-activity. The results of different chemical and physical tests of cream showed that it could use topically in order to protect against skin infections caused by fungus.

\section{ACKNOWLEDGEMENT}

The authors wish to thank The Oxford college of pharmacy, Bangalore for providing facilities and carry out research work and also to Associate Professor Mrs. Surinder Kaur, Prof Dr. Gururaj S Kulkarni, Associate Professor Dr. Lavanya for their valuable support and guidance, and also thankful to Divya R, G D Sindhu, Tejaswini B, Charita M, Syed Huda, Sanjay Kumar G N, Abhishek Yadav, Venkat swamy, Sanjay G, Adarsh Gouda, Dr. Shashi Kumar Patil.

\section{FUNDING}

Nil

\section{AUTHORS CONTRIBUTIONS}

All the authors have contributed equally.

\section{CONFLICT OF INTERESTS}

\section{Declared none}

\section{REFERENCES}

1. Sweetman SC. Martindale: the complete drug reference. 33rd ed. London, UK: Pharmaceutical Press; 2002. p. 381.

2. The pharmaceutical codex. 11th ed. London, UK: Pharmaceutical Press; 1979. p. 181.

3. https://labtestsonline.org/conditions/fungal-infections. [Last accessed on 25 Aug 2021].

4. Lee CM, Maibach HI. Deep percutaneous penetration into muscles and joints. J Pharm Sci. 2006;95(7):1405-13. doi: 10.1002/jps.20666, PMID 16729269.

5. Lim EH, Kim HR, Park YO, Lee Y, Seo YJ, Kim CD, Lee JH, Im M. Toenail onychomycosis treated with a fractional carbondioxide laser and topical antifungal cream. J Am Acad Dermatol. 2014 May 1;70(5):918-23. doi: 10.1016/j.jaad.2014.01.893, PMID 24655819.

6. Neubert RH. Potentials of new nanocarriers for dermal and transdermal drug delivery. Eur J Pharm Biopharm. 2011;77(1):1-2. doi: 10.1016/j.ejpb.2010.11.003. PMID 21111043.

7. Benson HA. Elastic liposomes for topical and transdermal drug delivery. Curr Drug Deliv. 2009;6(3):217-26. doi: 10.2174/156720109788680813, PMID 19604135.

8. Purushotham Rao K, Khaliq K, Kharat SS, Sagare P, Patil SK. Preparation and evaluation of $\mathrm{o} / \mathrm{w}$ cream for skin psoriasis. Int J Pharm Biol Sci. 2010;1:3.

9. Ind Std, Specification for Hair Creams, ind std institution, Manak Bhvan, bahadur Shah Zafar Marg, New Dehli-110002. 1st ed; 1978. p. 11-2.

10. Herbert LA. Pharmaceutical dosage forms. Rheology of dispersed systems; 1998. p. 367-422.

11. Baudonnet L, Grossiord JL, Rodriguez F. Physicochemical characterization and in vitro release of salicylic acid from $0 / \mathrm{W}$ emulsions prepared with Montanov 68: effect of formulation parameters. Drug Dev Ind Pharm. 2004;30(9):975-84. doi: 10.1081/ddc-200037251, PMID 15554222.

12. Kydonieus AF. Transdermal delivery of drugs. Vol. 1. CRC Press: Bocaraton; 1987. p. 168.

13. Patel J, Patel B, Banwait H, Parmar K, Patel M. Formulation and evaluation of topical aceclofenac gel using different gelling agent. Int J Drug Dev Res 2011;3:156-64.

14. Parmar RB, Baria AH, Faldu SD, Tank HM. Design and evaluation of poly-herbal formulation in semisolid dosage form for its antibacterial activity. J Pharm Res. 2009;2:1095-7.

15. More BH, Sakharwade SN, Tembhurne SV, Sakarkar DM. Evaluation for skin irritancy testing of developed formulations containing extract of Butea monosperma for its topical application. Int J Toxicol Appl Pharmacol. 2013;3:10-3.

16. OECD. 404, Guideline for the testing of Chemicals; 2021.

17. Sanna V, Peana AT, Mario D, Moretti L. Development of new topical formulations of diphenhydramine hydrochloride: in vitro diffusion and in vivo preliminary studies. Int J Pharm Technol Res. 2010;2:863-89.

18. Chen MX, Alexander KS, Baki G. Formulation and evaluation of antibacterial creams and gels containing metal ions for topical application, Hindawi publishing corporation. J Pharm 2016(5):1-10.

19. Maha HL, Sinaga KR, Sinaga KR, Masfria M, Masfria M. Formulation AND evaluation of miconazole nitrate nanoemulsion AND cream. Asian J Pharm Clin Res. 2018;11(3):319-21. doi: 10.22159/ajpcr.2018.v11i3.22056. 
20. Premkumar A, Muthukumaran T, Ganesan V, Shanmugam R, Priyanka D. Formulation and evaluation of cream containing antifungal agents, antibacterial agents and corticosteroids, Hygeia. JD Med 2014;6(2):5-16.

21. Calvo MA, Arosemena EL, Shiva C, Adelantado C. Antimicrobial activity of natural plant extracts and essential oils. Science against microbial pathogens: communicating current research and technological advances; 2011. p. 1179-85.

22. Dethier B, Nott K, Fauconnier ML. (BIO) Synthesis, extraction and purification of garlic derivatives showing therapeutic properties. Commun Agric Appl Biol Sci 2013;78:149-55. 